東京湾多摩川河口干潟におけるムロミスナウミナナフシ Cyathura muromiensis (甲殼綱：等脚目）の分布と生息環境特性

\title{
Distribution and Habitat Characteristics of Cyathura muromiensis (Crustacea: Isopoda) in the Tidal Flats of the Tama River Estuary, Tokyo Bay, Japan
}

\author{
堀越彩香* ・青木 茂・岡本 研 \\ 東京大学大学院農学生命科学研究科. $\bar{T} 113-8657$ 東京都文京区弥生 1-1-1 \\ Ayaka HORIKOSHI*, Shigeru AOKI and Ken OKAMOTO \\ Graduate School of Agricultural and Life Sciences, the University of Tokyo. 1-1-1 Yayoi, Bunkyo-ku, Tokyo, 113-8657 Japan
}

\begin{abstract}
To clarify the habitat characteristics of the brackish-water isopod Cyathura muromiensis, we conducted a field survey of the macrobenthic invertebrates, including C. muromiensis, and several environmental variables at 27 sites (3 stations $\times 9$ transect lines) on the tidal flats of the Tama River Estuary (Tokyo Bay, Japan) in summer in 2007 and 2009. Cyathura muromiensis was concentrated along certain transect lines between $0.5 \mathrm{~km}$ below and $2 \mathrm{~km}$ above the river mouth and was often limited to the shoreward stations. Canonical correspondence analysis (CCA) indicated that the major macrobenthic species may be distributed in response to two integrated environmental gradients: one is longitudinal and correlated with distance from the river mouth (as an indicator of salinity), median sediment grain diameter, and elevation; the other is not longitudinal but is correlated with the beach slope and sediment redox potential (ORP). The response pattern of $C$. muromiensis to the latter gradient distinguished this isopod from the other major macrobenthic species. The distribution of $C$. muromiensis along the gradient of each environmental variable selected by CCA was also checked. This isopod occurred abundantly at sites of mesohaline to polyhaline interstitial water in oxidized sandy sediment containing $2-18 \%$ mud and showing $60-140$ $\mathrm{mV}$ ORP at $5 \mathrm{~cm}$ depth, in the middle to lower intertidal zone of mildly sloping $(<0.8$ degree slope) beaches. These results indicate that mildly-sloped and well-oxygenated beach areas are distinctive habitat characteristics of C. muromiensis.
\end{abstract}

Key Words: CCA, Cyathura muromiensis, distribution, environment, estuary, geomorphology, redox potential, tidal flat

\section{はじめに}

ムロミスナウミナナフシ Cyathura muromiensis Nunomura, 1974 (等脚目スナウミナナフシ科) は, 黄白色で細長い形 態をした体長 $1.5 \mathrm{~cm}$ 前後の底生の小型甲殼類であり, 日本 各地の河口域の砂泥底に生息する（布村 1995; 飯島・和田 2007). 本種の属する等脚目は全般的に生息状況に関する 過去の調査が少ないため（布村 2007）, 地域絶滅や希少性 などを判断できる種がほとんどない，その中で本種は，干 潟の底生生物調査が進展した 1970 年代以降の調査報告の 分析により，東京湾において近年個体数の減少が著しい 「危機種」とされている（風呂田 2007, 2011）。しかし，そ の生態学的研究はほとんど行われておらず, 近年の個体数 減少の原因や保全に向けた留意点を議論するために不可欠 な生息環境特性についても，「河口近くの砂干潟」（市川 市・東邦大学東京湾生態系研究センター 2007）としか知

Received 2 June 2011 Accepted 30 August 2011

*Corresponding author

E-mail: horikoshi1373@yahoo.co.jp
られていない.

本研究では，本種の生息環境特性を明らかにするため に，東京湾多摩川河口域の左岸干潟において，本種を含む 主要なマクロベントスの分布と環境を調査し, その関係を 解析した。他のマクロベントスを解析に含めたのは, 生態 的知見の得られている種と比較することで, 本種の特徴が より明らかになると考えたためである。また環境について は, 河口域のマクロベントスの分布規定要因としてょく知 られる塩分と底質に加え, 地形環境も調べることで, より 詳細な環境特性の把握を目指した。なお，本研究では環境 として上記の物理的環境のみを対象とし, 生物的環境は考 慮しなかった。

\section{方 法}

\section{調査地}

調査は，東京湾の西奥に位置する多摩川河口域の左岸側 の干潟（東京都大田区）で行った（Fig. 1). 河口原点（旧 建設省による設置であり, 現在はその下流に河口延長水路 が存在する）から上流に約 $4 \mathrm{~km}$, 下流に約 $0.5 \mathrm{~km}$ の範囲 に0.5〜 $1 \mathrm{~km}$ 間隔で 9 本のトランセクトライン（上流から 


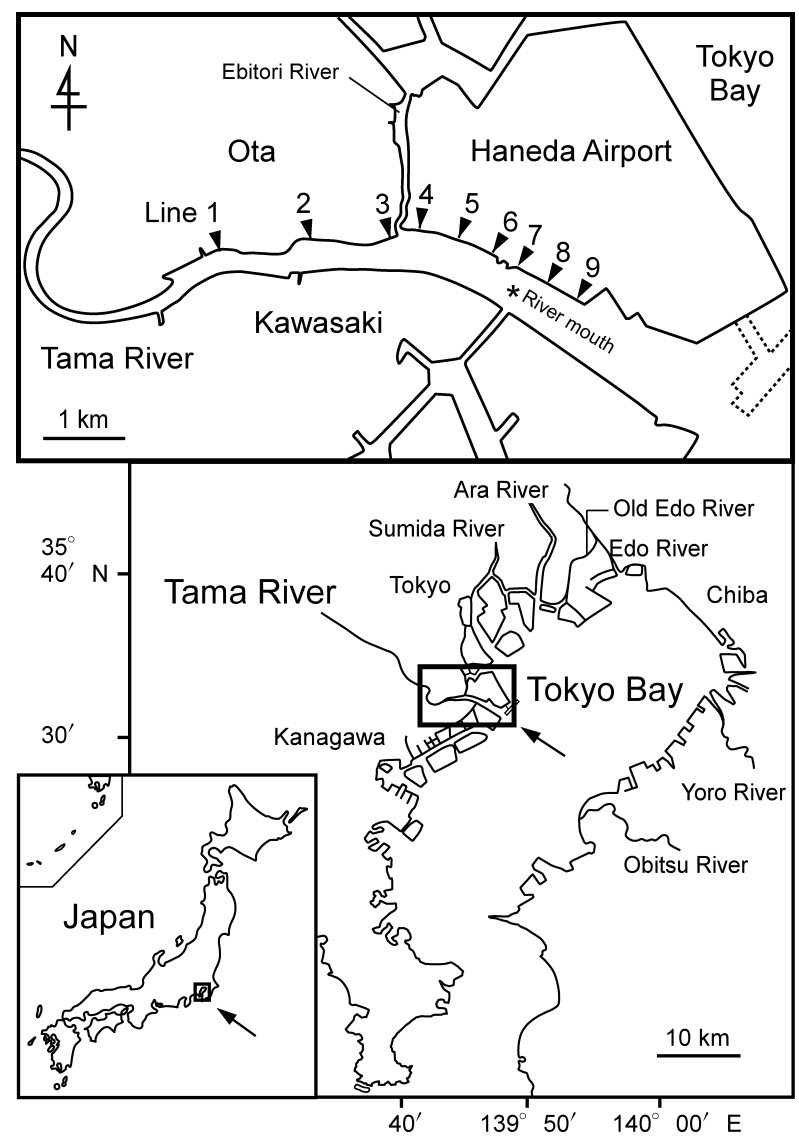

Fig. 1. Maps showing the location of the study area (the Tama River Estuary) in Tokyo Bay, Japan, and the locations of the nine transect lines (arrowheads). Three sampling stations: the shoreward, mid, and near low-water level stations (St. A, B, and C, respectively) were placed on each line (for details see Fig. 4). The river mouth $\left(^{*}\right)$ is the point marked as the zero-km origin of the river by the Construction Ministry (currently the Ministry of Land, Infrastructure, Transport and Tourism).

ライン 1〜9）を設け，ラインごとに，岸側・中央・低潮 線側の 3 定点（それぞれ定点 $\mathrm{A}, \mathrm{B}, \mathrm{C}$ ) を定めた。この 27 調査地点においてマクロベントスの採集と環境の測定を 行った.

\section{マクロベントス調査}

ムロミスナウミナナフシを含むマクロベントスの採集 は，2007年 8月 11〜26日と2009年7月 21〜23日の干潮時 に行った，夏に採集したのは，ムロミスナウミナナフシの 生活史 (著者ら未発表) の中で初期減耗中にあたり個体 数把握が難しい春や, 日の最干潮時刻が夜間となり調査が 難しい秋〜冬を避けたためである. 各調査地点において現 場で一定量の砂泥（2007年：0.1875 m², 深さ $10 \mathrm{~cm} ; 2009$ 年 $: 0.133 \mathrm{~m}^{2}$, 深さ $20 \mathrm{~cm}$ ) を網目 $0.5 \mathrm{~mm}$ の篩にかけ, 篩上 に残ったサンプルを実験室に持ち帰り，ただちに $10 \%$ ホ ルマリンで固定した. 後日, サンプルからマクロベントス をソーティングし, 肉眼あるいは実体顕微鏡下で種同定を したのち, 種ごとに個体数を計数し, $1 \mathrm{~m}^{2}$ 当たりの密度を
算出した。種同定に際しては鈴木ら（2000），西・田中 （2007），川合・谷田（2005）を参照し，種まで同定できな かったものはそれよりも上の分類群でとどめた。

\section{環境調査}

河川流軸方向の位置情報として, 河口原点から各調査ラ インまでの距離を地図上で測定し，下流方向にはマイナス の符号をつけた。 また，いくつかのラインで底質間隙水ま たは直上水の塩分を測定した。 ライン 4, 7,9では2007年の 秋（11月20～25日)，2008年の冬（2月22～25日），春（5 月 19〜23日), 夏（8月 17〜 19日）の干潮時に堆積物を掘 り，浸み出た水の塩分を小型水質計（ハンディメーター Model 85, YSI）により測定した。ライン1では2008年の冬 （3月8～21日）と春（4月 10～23日）に，底質表面から 7 $\mathrm{cm}$ 上に設置した小型メモリー水温塩分計（COMPACT-CT Model ACT-HR, JFEアレック）により，直上水の塩分を 1 分間隔で 2 週間連続観測した。

地形環境として，2007年8月27〜29日の干潮時に自動 レベル（ $\mathrm{Cl}_{3}$,ソキア）を用いて各ラインで水準測量をおこ ない，作成した地形断面図をもとに，各調査地点の標高と 斜度，また各ラインの干潟の幅を算出した。測量の際は護 岸あるいはアシ原の終わりから低潮線付近までの間に調査 地点を含めて 9〜14測量点を設定し，各測量点の標高は測 量時刻の水位との差に基づいて算出した．斜度はライン上 で前後の 2 測量点を結んだ角度とし，岸から低潮線方向に 向かって下り勾配であればマイナスの符号をつけた。干潟 の幅は護岸あるいはアシ原の終わりから大潮平均低潮面ま での水平距離とした。多摩川縦断面図（山本 2008）を参 考にすると平均大潮満潮位および平均干潮位のライン 1 と 9の間の差はそれぞれ約 $10 \mathrm{~cm}$ および約 $5 \mathrm{~cm}$ と推定される ことから，調査範囲における河川流軸方向の水位勾配は無 視できる程度と判断し，すべてのラインにおいて，測量時 刻水位と大潮平均低潮面・高潮面の標高は, 国土交通省河 川局の水文水質データベース（http://www1.river.go.jp/）で 公開されている多摩川河口観測所の毎時水位観測データか ら計算した。

底質環境として, 各調査地点における酸化還元電位 (ORP), 泥分率, 中央粒径值, 含水率, 有機炭素含有率 （TOC），窒素含有率（TN）を測定した。ORPは，2009年 8 月21日の干潮時に，ORP電極（9300-10D，HORIBA）を用 いて底質表面から $5 \mathrm{~cm}$ の深さで 2 回測定し平均值を算出し た. 残りの項目の分析には，2007年と2009年のマクロ心゙ ントス調査時に採取した表層2〜 $5 \mathrm{~cm}$ の堆積物を用いた。 含水率は, $70^{\circ} \mathrm{Cで}$ 恒量となるまで乾燥させた堆積物の乾燥 重量と湿重量の差から求めた。 TOC・TNは, 乾燥させた 堆積物に $1 \mathrm{M}$ 塩酸を加えて炭酸塩を除去したあと, CN コーダー（MT-700，柳本製作所）を用いて測定した。中 央粒径值と泥分率は篩分け分析法（石塚 1986）により分 析した。これらは 2 年間の平均值を算出した。 


\section{分布と環境の関係の解析}

ムロミスナウミナナフシを含む主要なマクロベントスの 分布と環境との関係について, その全体的なパターンを把 握するため, 正準対応分析 Canonical correspondence analysis（CCA）を行った。CCAでは事前に対象種の最適環境に ついての知見がなくても解析でき, 環境間の関係や種間の 関係も把握できる（加藤・篠沢 1995）点で, 本研究の目 的に適していた。種データには, 属以下まで同定され, 過 半数の地点で出現し, 最高密度が 100 個体 $/ \mathrm{m}^{2}$ 以上で あった，ムロミスナウミナナフシを含む11種（Table 1 に ○で示す）を用いた。種データの值は2007年と2009年の 平均個体数密度 $(\mathrm{x})$ を $\log (\mathrm{x}+1)$ 変換した。環境データに は, 河口原点からの距離, 干潟の幅, 標高, 斜度, ORP, 泥分率, 中央粒径值, 含水率, $\mathrm{TOC}, \mathrm{TN}, \mathrm{C} / \mathrm{N}$ 比の 11 項目 を用いた。環境データは, 種データの分散に有意に関係し ている項目に絞るため, Monte Carlo permutation testによる forward selectionを行った. 有意水準はKanaya \& Kikuchi （2008）に準じ $p<0.1$ とした. 以上の解析ソフトウェアに はCANOCO 4.5（ter Braak \& Smilauer 2002）を用いた。そ の後, ムロミスナウミナナフシの生息環境の具体值を明ら かにするために, CCAの forward selectionで選択された環 境要因を中心として, 塩分, 底質粒度 (中央粒径值と泥分 率), 標高, 斜度, ORPの勾配に対する本種の個体数密度 を調べた。

\section{結果}

\section{ムロミスナウミナナフシと主要種の空間分布}

マクロベントス調査の結果, 2007 年と2009年をあわせ 多摩川河口左岸干潟には34タクサのマクロベントスが出 現した (Table 1).このうちムロミスナウミナナフシを含 む主要種の空間分布を Fig. 2 に示す. 出現種やその分布に 年による大きな違いはなかったため, 結果はすべて 2 年の 平均值で表した。

Fig. $2 \mathrm{i}$ から，ムロミスナウミナナフシの分布の特徵を述 ベる. 河川流軸方向の分布範囲に着目すると, 本種はライ ン1では不在, ライン 2 では出現量が極めて少なく, 主な 分布範囲はライン 3 9であった。これは河口原点から上 流へ約 $2 \mathrm{~km}$, 下流へ約 $0.5 \mathrm{~km}$ の範囲であった。 その中で も本種の分布はライン $4,7,8,9$ に集中し, ライン $3,5,6$ に おける出現量は隣接するラインに比べ顕著に低下してい た。 またライン内の分布に着目すると，本種はほとんどの ラインで岸側の定点 $\mathrm{A} に$ 限られた, または著しく偏った狭 い分布を示した。この岸側限定分布はライン9では見られ ず，本種はライン上に広く分布した。

以上の特徵を他の主要種の分布（Fig. $2 \mathrm{a} \sim \mathrm{h}, \mathrm{j}, \mathrm{k}$ ) と比較 する.ムロミスナウミナナフシの河川流軸方向の主な分布 範囲は本種に特有ではなく, Heteromastus sp., ドロオニス ピオ Pseudopolydora kempi, ヤマトスピオ Prionospio japoni-
Table 1. Macrobenthic invertebrates found at 27 sites in the Tama River Estuary in the summers of 2007 and 2009. For each species, mean ( \pm SD) and maximum (Max.) density (number of individuals per $\mathrm{m}^{2}$ ) of the 27 sites were calculated from the local densities that were estimated at each site by taking the average of the densities in 2007 and 2009. Frequency (Freq.) is the number of sites at which a particular species occurred. Species that were collected from more than 14 sites and had a maximum density of more than 100 individuals per $\mathrm{m}^{2}$ were deemed major macrobenthic species $(\bigcirc)$ for the canonical correspondence analysis (CCA); Cyathura muromiensis was one of these.

\begin{tabular}{|c|c|c|c|c|}
\hline \multirow{2}{*}{ Taxa } & \multicolumn{2}{|c|}{ Density (indiv. $\mathrm{m}^{-2}$ ) } & \multirow{2}{*}{ Freq. } & \multirow{2}{*}{ CCA } \\
\hline & Mean $\pm S D$ & Max. & & \\
\hline \multicolumn{5}{|l|}{ Nemertea } \\
\hline Nemertea & $9 \pm 14$ & 53 & 14 & \\
\hline \multicolumn{5}{|l|}{ Mollusca } \\
\hline Assiminea sp. & $0.9 \pm 4.2$ & 22 & 2 & \\
\hline Stenothyra edogawaensis & $0.1 \pm 0.8$ & 4 & 1 & \\
\hline Nassarius festivus & $0.3 \pm 1.4$ & 8 & 1 & \\
\hline Xenostrobus securis & $0.3 \pm 1.0$ & 4 & 3 & \\
\hline Musculista senhousia & $17 \pm 58$ & 305 & 12 & \\
\hline Mactra veneriformis & $39 \pm 71$ & 255 & 11 & \\
\hline Solen strictus & $6 \pm 11$ & 34 & 9 & \\
\hline Corbicula japonica & $166 \pm 158$ & 587 & 25 & $\bigcirc$ \\
\hline Mercenaria mercenaria & $1 \pm 2.8$ & 12 & 4 & \\
\hline Ruditapes philippinarum & $41 \pm 89$ & 350 & 16 & $\bigcirc$ \\
\hline Meretrix lusoria & $0.1 \pm 0.8$ & 4 & 1 & \\
\hline Cyclina sinensis & $0.3 \pm 1.1$ & 4 & 2 & \\
\hline Laternula marilina & $7 \pm 12$ & 49 & 15 & \\
\hline \multicolumn{5}{|l|}{ Annelida } \\
\hline Eteone sp. cf. longa & $89 \pm 108$ & 459 & 23 & O \\
\hline Glycera sp. & $2 \pm 4$ & 13 & 6 & \\
\hline Sigambra phuketensis & $2 \pm 6$ & 23 & 4 & \\
\hline Ceratonereis erythraeensis & $9 \pm 23$ & 105 & 8 & \\
\hline Neanthes succinea & $0.1 \pm 0.5$ & 3 & 1 & \\
\hline $\begin{array}{l}\text { Hediste sp. or spp. } \\
\text { (diadroma and/or atoka) }\end{array}$ & $1936 \pm 1348$ & 4180 & 27 & $\bigcirc$ \\
\hline Tylorrhynchus heterochaetus & $0.3 \pm 1.7$ & 9 & 1 & \\
\hline Prionospio japonica & $453 \pm 465$ & 1884 & 27 & $\bigcirc$ \\
\hline Pseudopolydora kempi & $544 \pm 710$ & 2679 & 27 & $\bigcirc$ \\
\hline Heteromastus sp. & $387 \pm 524$ & 2185 & 26 & 0 \\
\hline Notomastus sp. & $79 \pm 136$ & 509 & 16 & $\bigcirc$ \\
\hline Capitella sp. & $27 \pm 39$ & 128 & 19 & ○ \\
\hline Capitellidae gen. et sp. & $2 \pm 12$ & 65 & 1 & \\
\hline Armandia amakusaensis & $48 \pm 89$ & 361 & 14 & 0 \\
\hline \multicolumn{5}{|l|}{ Crustacea } \\
\hline Copepoda & $3 \pm 13$ & 66 & 3 & \\
\hline Cyathura muromiensis & $83 \pm 135$ & 451 & 18 & $\bigcirc$ \\
\hline Grandidierella japonica & $14 \pm 19$ & 71 & 17 & \\
\hline Melita $\mathrm{sp}$. & $3 \pm 13$ & 69 & 3 & \\
\hline Cumacea & $46 \pm 76$ & 286 & 15 & \\
\hline \multicolumn{5}{|l|}{ Insecta } \\
\hline Dolichopodidae gen. et sp. & $0.2 \pm 1.1$ & 6 & 1 & \\
\hline All macrobenthos & 4016 & & & \\
\hline
\end{tabular}

ca, ホソミサシバ近似種Eteone sp. cf. longa, Capitella sp. も 本種と同様の分布範囲（ライン2９あるいは3〜9）を示 した.また本種の分布範囲は, Notomastus sp.（主にライ ン 1〜4に分布）より海側, ヤマトシジミ Corbicula japonica 


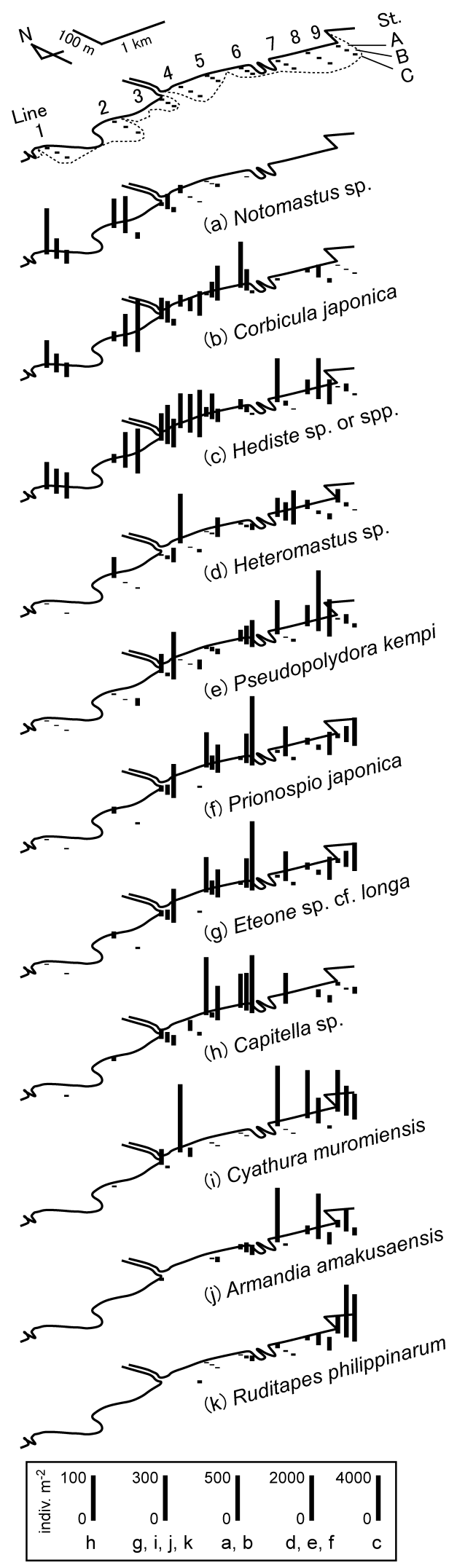

Fig. 2. Spatial distributions of the 11 major macrobenthic species in the Tama River Estuary. Column length indicates density (indiv. $\mathrm{m}^{-2}$ ) calculated as the mean of the densities recorded in the summers of 2007 and 2009. Note that scales differ for different species as indicated in the box.
（同，ライン 1 8）とは広く重複しながらも全体として海 側，アサリRuditapes philippinarum（同，ライン 8〜9）と ツツオオフェリアArmandia amakusaensis（同，ライン6〜 9）とは部分的に重複しながら全体として上流側であった. 一方，河川流軸方向の主な分布範囲における特定ラインへ の集中分布や岸側定点への限定分布は, 他の主要種には見 られない，本種に特有のものであった，ただし，Capitella sp. とホソミサシバ近似種は, ライン $3,5,6$ において本種と 対照的な個体数増加傾向を示した。

\section{調査地の環境}

環境調査の結果を Table 2 に示す。これらの環境項目の うち，ORP以外の底質環境項目間やそれらと河口原点か らの距離の間, 標高と河口原点からの距離または中央粒径 值の間，干潟の幅・斜度・ORPの間には有意 $(p<0.05)$ な 相関があった。すなわち，上流側の調査地点ほど底質の粒 子が小さく, 泥・水分・有機物の含量が高く, 標高が高い 傾向にあり，これらとは独立に，干潟の幅が広いほど斜度 が小さく ORPは高い傾向があった。

Fig. 3 には地形断面図を示す.ライン $3,5,6$ では干潟の 幅が $30 \mathrm{~m}$ 前後と狭く, 全体的に傾斜が急であった一方, ライン $1,2,4,8$ では干潟の幅が $100 \mathrm{~m}$ 前後と広く, 全体的 に傾斜が緩かった。またほとんどのラインで岸側で凹，そ の後低潮線に向かって凸カーブを描きながら下る地形を示 し，そのため定点 $\mathrm{A} て ゙$ 斜度が 0 に近いかわずかにプラスの 值をとる窪地となっていた。例外的にライン9では岸から 低潮線の手前まで平坦な地形が続いていた。

Fig. 4 には河口原点からの距離に対する底質間隙水また は直上水塩分の年間範囲と平均值を示す．塩分は下流側ほ ど高い傾向があり，河口原点からの距離は塩分の指標とし て考えてよいことが示された。

\section{CCAを用いた分布と環境の関係の解析}

CCAの forward selectionでは, 河口原点からの距離・中 央粒径值・標高・斜度 $($ 以上 $p<0.01) \cdot \mathrm{ORP}(p=0.076)$ が選択された。これら 5 項目を用いたCCAの結果，得ら れたモデルは第2正準軸（以下，軸と記述）までで種デー タの分散の $67.0 \%$ を説明した（Table 3). 第1軸には河口原 点からの距離と標高が正の相関，中央粒径值が負の相関を 有し，第2軸には斜度とORPが正の相関を有していた。つ まり，ムロミスナウミナナフシを含む主要なマクロベント スは, 河口原点からの距離（塩分の指標とみなせる）・中 央粒径值・標高と相関する環境勾配と，それとは独立で斜 度・ORPと相関する環境勾配とに応答して分布していた ことが示された。

CCA で得られたモデルの第 1 ・第2軸に対する地点の配 置と種の配置を Fig. 5 に示す．地点の配置（Fig. 5a）では, 第 1 軸上で右から左にライン 1 9が順に配置された。これ は第 1 軸が河川流軸方向の環境勾配であること，上流側の 
Table 2. Environmental variables at 27 sites in the Tama River Estuary. TOC, total organic carbon content; TN, total nitrogen content; C/N, carbon/nitrogen ratio; ORP, redox potential. Geomorphological characteristics were measured in the summer of 2009 using a level. Sediment ORP is presented as the average of twice-replicated measurements at $5 \mathrm{~cm}$ below the surface in the summer of 2009. Other features are shown as the means of measurements made in the summers of 2007 and 2009 from the 3-5 cm layer below the surface.

\begin{tabular}{|c|c|c|c|c|c|c|c|c|c|c|c|}
\hline \multirow[b]{2}{*}{$\begin{array}{c}\text { Site } \\
\text { (Line-St.) }\end{array}$} & \multirow{2}{*}{$\begin{array}{l}\text { Distance } \\
\text { from river } \\
\text { mouth } \\
(\mathrm{km})\end{array}$} & \multicolumn{3}{|c|}{ Geomorphology } & \multicolumn{7}{|c|}{ Sediment } \\
\hline & & $\begin{array}{l}\text { Width of } \\
\text { tidal flat } \\
\text { (m) }\end{array}$ & $\begin{array}{c}\text { Slope } \\
\text { (degree) }\end{array}$ & $\begin{array}{c}\text { Elevation } \\
(\mathrm{cm})\end{array}$ & $\begin{array}{l}\text { Median } \\
\text { grain size } \\
\quad(\mu \mathrm{m})\end{array}$ & $\begin{array}{c}\text { Mud } \\
\text { content } \\
(\%)\end{array}$ & $\begin{array}{c}\text { Water } \\
\text { content } \\
(\%)\end{array}$ & $\begin{array}{l}\text { TOC } \\
(\%)\end{array}$ & $\begin{array}{l}\mathrm{TN} \\
(\%)\end{array}$ & $\mathrm{C} / \mathrm{N}$ & $\begin{array}{l}\text { ORP } \\
(\mathrm{mV})\end{array}$ \\
\hline $1-\mathrm{A}$ & 3.9 & 82 & 0.45 & 8.9 & 88 & 40.7 & 40.9 & 1.46 & 0.104 & 13.7 & 63 \\
\hline $1-\mathrm{B}$ & & & -0.63 & 24.4 & 139 & 4.7 & 31.7 & 0.36 & 0.045 & 8.3 & 108 \\
\hline $1-\mathrm{C}$ & & & -1.32 & -15.1 & 156 & 3.4 & 32.3 & 0.28 & 0.036 & 7.4 & 111 \\
\hline $2-\mathrm{A}$ & 2.8 & 107 & -0.63 & -9.6 & 75 & 44.7 & 31.8 & 1.01 & 0.065 & 15.2 & 50 \\
\hline $2-B$ & & & 0.01 & -10.1 & 79 & 35.8 & 36.9 & 1.06 & 0.086 & 12.2 & 109 \\
\hline $2-\mathrm{C}$ & & & -0.63 & -34.6 & 127 & 7.4 & 30.0 & 0.42 & 0.047 & 8.4 & 107 \\
\hline $3-\mathrm{A}$ & 1.8 & 25 & -3.03 & -16.0 & 151 & 8.1 & 29.5 & 0.84 & 0.056 & 13.7 & 94 \\
\hline $3-\mathrm{B}$ & & & -0.33 & -27.0 & 190 & 3.8 & 26.0 & 0.34 & 0.045 & 7.7 & 58 \\
\hline $3-\mathrm{C}$ & & & -4.69 & -55.5 & 104 & 25.7 & 36.3 & 0.95 & 0.083 & 10.3 & 63 \\
\hline $4-\mathrm{A}$ & 1.6 & 93 & 0.24 & -1.6 & 99 & 18.5 & 31.9 & 0.65 & 0.062 & 10.8 & 120 \\
\hline $4-\mathrm{B}$ & & & -0.75 & 2.9 & 167 & 2.9 & 29.4 & 0.31 & 0.035 & 8.2 & 96 \\
\hline $4-\mathrm{C}$ & & & -0.75 & -28.1 & 140 & 10.9 & 32.6 & 0.46 & 0.050 & 9.6 & 129 \\
\hline $5-\mathrm{A}$ & 1.2 & 26 & -3.83 & -15.8 & 269 & 0.7 & 21.6 & 0.14 & 0.022 & 5.8 & -24 \\
\hline $5-\mathrm{B}$ & & & -2.52 & -46.8 & 216 & 3.5 & 24.1 & 0.20 & 0.029 & 7.0 & 33 \\
\hline 5-C & & & -1.60 & -81.8 & 152 & 10.4 & 29.1 & 0.34 & 0.037 & 9.0 & 116 \\
\hline 6-A & 0.6 & 35 & -2.75 & -18.0 & 191 & 1.9 & 24.7 & 0.21 & 0.034 & 6.5 & -59 \\
\hline $6-\mathrm{B}$ & & & -1.26 & -47.0 & 205 & 4.7 & 25.4 & 0.24 & 0.030 & 7.5 & 4 \\
\hline $6-\mathrm{C}$ & & & -1.43 & -72.0 & 229 & 12.6 & 27.5 & 0.47 & 0.046 & 9.8 & 56 \\
\hline 7-A & 0.3 & 57 & -0.75 & -27.8 & 234 & 4.5 & 25.4 & 0.28 & 0.032 & 8.2 & 115 \\
\hline 7-B & & & -0.80 & -45.3 & 197 & 4.6 & 23.8 & 0.25 & 0.029 & 8.2 & 87 \\
\hline 7-C & & & -1.32 & -70.3 & 116 & 27.0 & 32.0 & 0.65 & 0.058 & 11.0 & -15 \\
\hline 8-A & -0.2 & 106 & 0.04 & -42.9 & 288 & 2.5 & 26.3 & 0.27 & 0.031 & 8.6 & 136 \\
\hline 8-B & & & 0.07 & -42.9 & 262 & 2.8 & 24.6 & 0.22 & 0.030 & 7.6 & 61 \\
\hline $8-\mathrm{C}$ & & & -0.69 & -58.9 & 240 & 3.3 & 26.2 & 0.27 & 0.033 & 8.2 & 90 \\
\hline 9-A & -0.6 & 69 & -0.06 & -59.6 & 234 & 4.7 & 26.8 & 0.23 & 0.025 & 8.1 & 105 \\
\hline 9-B & & & 0.03 & -58.6 & 243 & 2.5 & 26.3 & 0.21 & 0.028 & 8.0 & 108 \\
\hline 9-C & & & -0.32 & -55.6 & 232 & 3.2 & 27.2 & 0.24 & 0.032 & 7.7 & 77 \\
\hline
\end{tabular}

ラインほど塩分が低く底質粒子が小さく標高が高いことを 意味する。一方，第2軸上では，ライン $3,5,6$ が他のライ ンょりも下方に配置され，ラインごとにみると定点 $\mathrm{A}, \mathrm{B}$, Cの順で上方から下方に配置される傾向があった。これは 第2軸が河川流軸方向の勾配とは独立した，ライン間やラ イン内の環境勾配であること, ライン $3,5,6$ は他のライン より, 定点Cは定点Aより傾斜が急で ORPが低いことを 意味する．また，ムロミスナウミナナフシの河川流軸方向 の主な分布範囲であるライン $3 \sim 9$ はそれ以外（ライン 1・2）と第 1 軸上で区別され，河川流軸方向の分布範囲内 で本種の偏ったまたは限られた分布が見られたライン 4,7 , 8,9 および各ライン内での定点 $\mathrm{A}$ はそれ以外（ライン 3,5, 6 , 定点 $\mathrm{B}, \mathrm{C})$ と第2軸上で区別された。これは, 本種の
河川流軸方向の主な分布範囲には塩分・中央粒径值・標高 が関連し，本種の限定分布には斜度と ORPが関連してい ることを意味する。

同様に，種の配置（Fig. 5b）では，第1軸上でもっとも 右にNotomastus sp., もっとも左にアサリとッツオオフェ リアが配置され，残りの種はそれらの間に散在的に配置さ れた。これはNotomastus sp.はもっとも塩分が低く底質粒 子が小さく標高が高いところ，アサリはその反対，ムロミ スナウミナナフシを含む残りの種はそれらの間で少しずつ 異なるところに分布中心をもつことを意味する，一方，第 2軸上では, 上方にムロミスナウミナナフシ, 下方にホソ ミサシバ近似種と Capitella sp., 原点付近に残りの種が配 置された。これはムロミスナウミナナフシは傾斜が緩く 


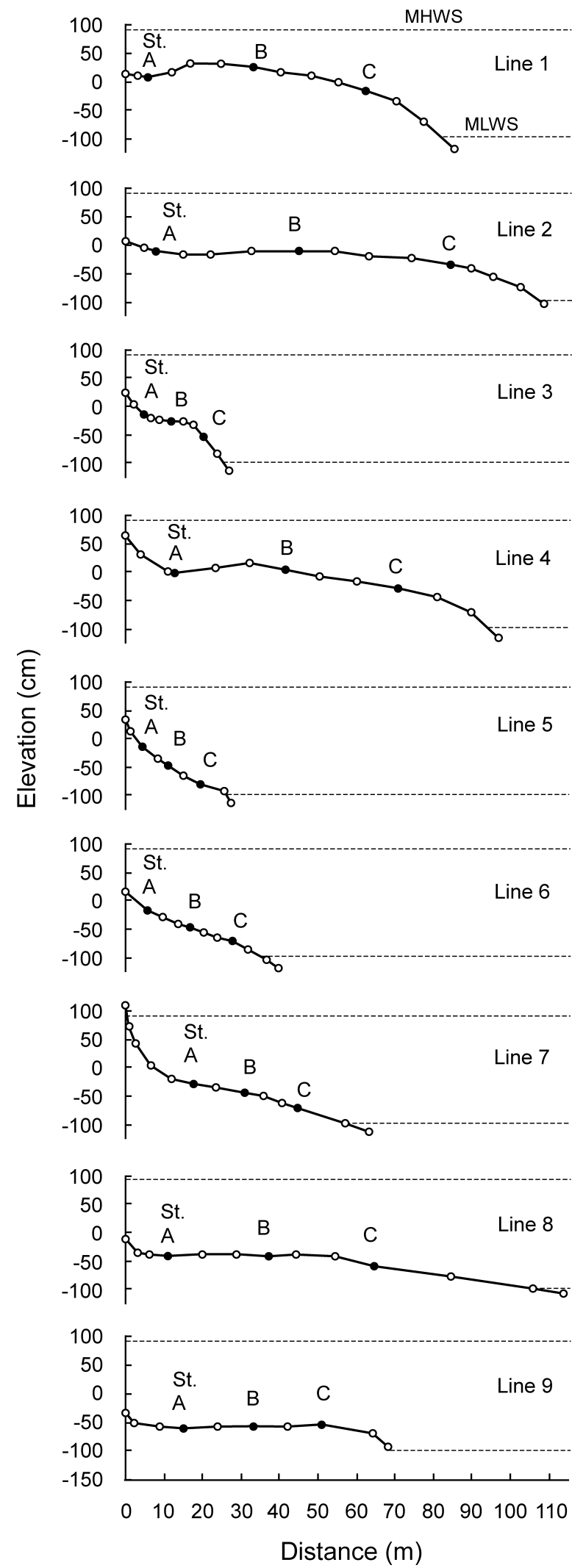

Fig. 3. Intertidal profiles of each transect line. Elevation is height above sea level of Tokyo Bay. Circles indicate leveling points, and closed circles indicate sampling stations for macrobenthic invertebrates and environmental variables. Dotted lines indicate the mean high water springs (MHWS, upper) and the mean low water springs (MLWS, lower).
ORPが高いところ，ホソミサシバ近似種と Capitella sp.は その反対，残りの種はこれらの勾配の中央付近に分布中心 をもつことを示唆している．また，以上に述べたようにム ロミスナウミナナフシは第2軸上で他の主要種から明瞭に 区別されたことから，主要種の中で本種に特有だったのは 斜度とORPに対する応答の仕方であることが示唆された。

\section{各環境要因に対するムロミスナウミナナフシの分布}

CCAで抽出された環境要因に対するムロミスナウミナ ナフシの分布から，本種の生息環境特性を述べる.

塩分については，河川流軸方向のムロミスナウミナナフ シの主な分布範囲（Fig. 2i）と，いくつかのラインでの年 間塩分範囲（Fig. 4）を比較する。本種の主な分布範囲の最 上流端であるライン3では塩分測定ができなかったが，こ この塩分は $200 \mathrm{~m}$ 程度離れたライン 4 の塩分と大きく変わ らないと考えられ，ライン4の間隙水塩分は 5.5〜27 pptで あった。これはVenice system（IUBS 1959）の定義における

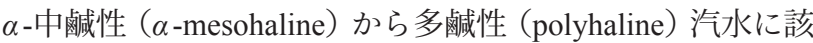
当した。一方，本種の分布範囲の最下流端であるライン 9 での間隙水塩分は21〜27 pptであり,これは多戙性汽水に 該当した。

底質の粒子サイズについては，本種が多く出現した地点 は，中央粒径值が $100 \sim 280 \mu \mathrm{m}$ で含泥率が $2 \sim 18 \%$ の砂質 であった (Fig. 6).

標高については，本種が多く出現した地点は標高が 10

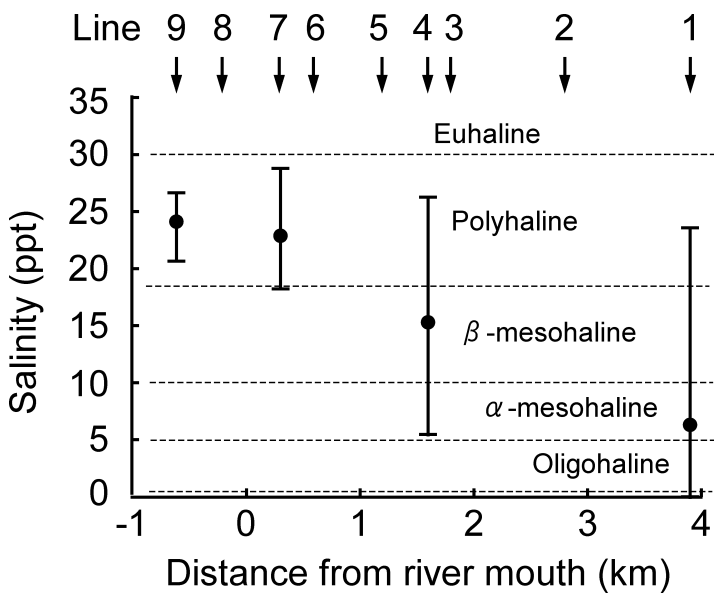

Fig. 4. Annual salinity range and annual average salinity along the Tama River. Arrows indicate the location of each transect line at which the macrobenthos was sampled and several environmental variables were measured. At Lines 4, 7, and 9, salinities of interstitial water of the sediment were measured in the autumn of 2007 and in the winter, spring, and summer of 2008 for use in calculating the mean (closed circles) and minimum and maximum (line caps) salinities. At Line 1, the salinity of water $7 \mathrm{~cm}$ above the sediment surface was recorded at 1-min intervals for two weeks from 8 to 21 March 2008 (low-rainfall season) and from 10 to 23 April 2008 (high-rainfall season), also for calculating the mean, minimum, and maximum salinities. 
Table 3. Summarized results of canonical correspondence analysis using abundance data for 11 major macrobenthic species ( $\bigcirc$ in Table 1 ) and five significant environmental variables selected from among 11 measured variables (Table 2) by forward selection (Monte Carlo permutation test, $p<0.1$ ) for 27 sites. Inter-set correlations between the significant first two canonical axes (Monte Carlo permutation test, $p<0.05$ ) are shown. Significant correlations between each environmental variable and the axes are indicated with asterisks: ***, $p<0.001 ;{ }^{* *}, p<0.01$.

\begin{tabular}{lcc}
\hline & Axis 1 & Axis 2 \\
\hline Eigenvalues & 0.158 & 0.035 \\
Species-environment correlations & 0.971 & 0.86 \\
Cumulative percentage variance & & \\
$\quad$ of species data & 54.7 & 67 \\
of species-environment relation & 75 & 91.8 \\
Inter-set correlations of environmental variables with axes & \\
Distance from river mouth & $0.9661^{* * *}$ & -0.0728 \\
Beach slope & -0.079 & $0.6459^{* * *}$ \\
Elevation & $0.6866^{* * *}$ & 0.3421 \\
Median grain size & $-0.7638^{* * *}$ & -0.0546 \\
Sediment ORP & 0.0866 & $0.5446^{* *}$ \\
\hline
\end{tabular}
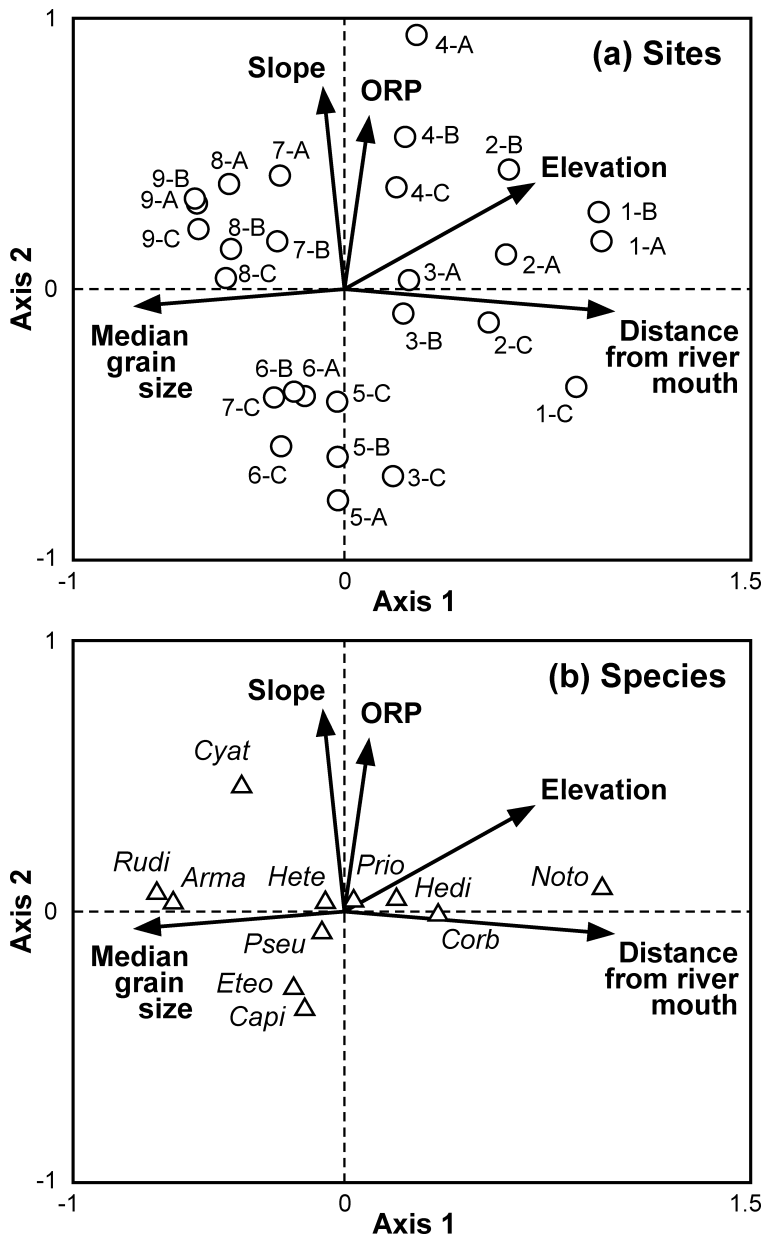

Fig. 5. Canonical correspondence analysis ordination diagrams: (a) site scores and (b) species scores. Arrows indicate environmental variables. Sites are indicated by line number (1-9) and station name $(\mathrm{A}-\mathrm{C})$. Species are indicated by the first four letters of their genus name (see Table 1).

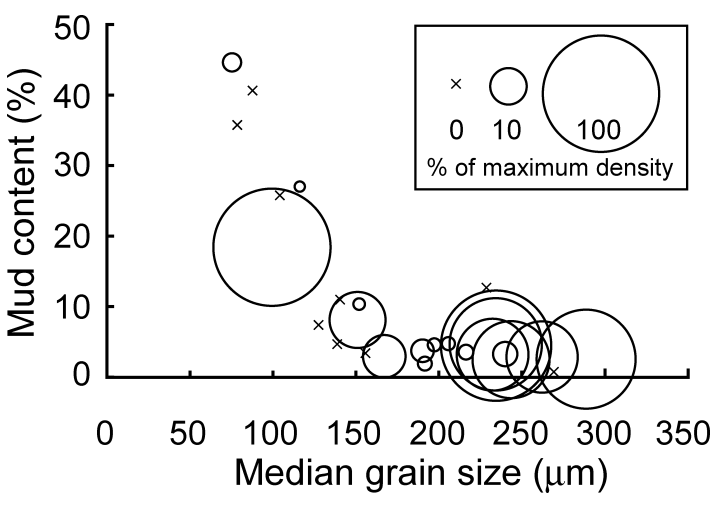

Fig. 6. Distribution of Cyathura muromiensis along the gradients of median grain size and mud content of the sediment. See Fig. 2 and Table 2 for data.

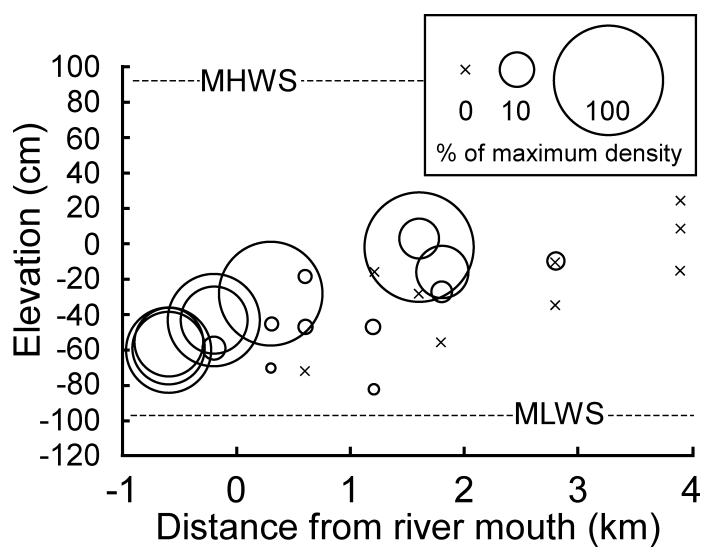

Fig. 7. Distribution of Cyathura muromiensis along the gradients of distance from the river mouth and elevation. MHWS, mean high water springs; MLWS, mean low water springs. See Fig. 2 and Table 2 for data. 


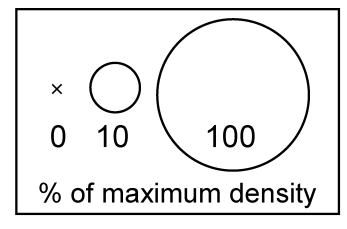

(a) Cyathura muromiensis
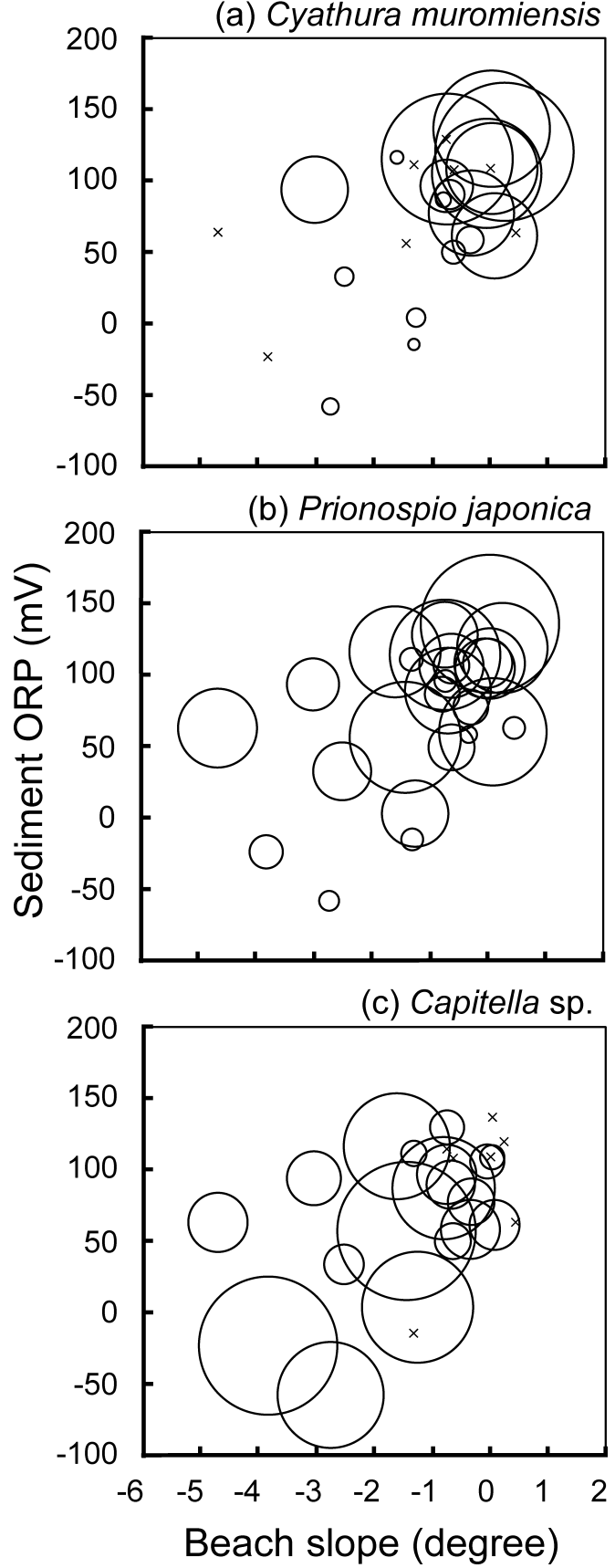

Fig. 8. Distributions of (a) Cyathura muromiensis, (b) Prionospio japonica, and (c) Capitella sp. along the gradients of beach slope and sediment ORP. See Fig. 2 and Table 2 for data.

〜ー60 cmで，これは調査地における潮間帯中部〜下部で あった (Fig. 7).

斜度と底質の ORP については，ムロミスナウミナナフ シが多く分布した場所は斜度がー $0.7 \sim 0.2^{\circ}$ で ORPが 60 〜
$140 \mathrm{mV}$ のころ，すなわち緩傾斜もしくはわずかな社地 で，底質の ORPが調查域の中で最も高く，深さ $5 \mathrm{~cm}$ でも 十分酸化的な場所であった（Fig. 8a). 対照的に, Capitella sp. が多く分布した場所は斜度がー3.8 - $0.8^{\circ}$ で ORPが - 60〜 $120 \mathrm{mV}$ のころ, すなわち調査域の中で最も傾斜 が急で，底質の ORPが低く，深さ $5 \mathrm{~cm}$ では還元的になっ ている場所も含んでいた（Fig. 8c）。ヤマトスピオは傾斜 が緩くORPの高いところに多く分布する点ではムロミス ナウミナナフシと同じであったが，傾斜が急でORPの低 いところまで広く分布する点で異なっていた（Fig. 8b). 他の主要種の分布は図に示していないが，ホソミサシバ近 似種でCapitella sp. と同様であったほかは，ヤマトスピオ と同様であり，ムロミスナウミナナフシほど緩傾斜・高 ORPに厳密な分布をした種はいなかった。

\section{考察}

\section{多摩川河口左岸干潟におけるムロミスナウミナナフシの分 布と生息環境特性}

本研究によって, 多摩川河口左岸干潟におけるムロミス ナウミナナフシの分布は，河口原点から上流へ約 $2 \mathrm{~km}$, 下流へ約 $0.5 \mathrm{~km}$ の範囲であり, その中でも特定のライン に集中し，さらに多くのラインでは岸側の定点に限定され ることがわかった（Fig. 2i)．CCAは本種を含む主要なマ クロベントスが互いに独立する2つの環境勾配に応答して 分布することを見出し，それは河口原点からの距離（塩分 の指標とみなせる）および底質の中央粒径值，標高と相関 する河川流軸方向の環境勾配と, 斜度および底質の ORP と相関する環境勾配であった（Fig. 5).CCAはまた，後者 の環境勾配に対する本種の応答パターンは，主要なマクロ ベントスの中で本種に特有であることを示した（Fig. 5b). これら，CCAで分布と関連が示された各環境要因につい て，本種が多く分布していた定点の值を本種の生息環境特 性とみなすと，それは，1）間隙水塩分が中揇性〜多嵅性 （mesohaline〜 polyhaline）で，2）2〜18\%の泥を含んだ中央 粒径が 100〜280 $\mu \mathrm{m}$ の砂質，3）潮間帯中〜下部，4） $0.8^{\circ}$ 未満の緩傾斜またはわずかな䇠地，5）底質のORPが深さ $5 \mathrm{~cm}$ で $60 \sim 140 \mathrm{mV}$ と十分酸化的な底質, であった（Figs. $4,6,7,8)$.

特性 1）からは，本種は淡水〜貧崴性汽水への耐性が低 いことが推察される。これは，本種の河川流軸方向の分布 範囲が，低楲性汽水種として知られる Notomastus sp.（山 室 1996）より海側, 高鹹性汽水種として知られるヤマト スピオや Heteromastus sp.（山室 1996）とほぼ同じ範囲で あった（Fig. 2)ことからも支持される。本研究ではライン 9より海側には立ち入れず，高塩分側の分布限界は明らか にできなかったが， $35 \mathrm{ppt}$ の海水中で本種の初期肧を飼育 すると発生が完了しない（著者ら未発表）ことから，本 種は海水には分布しないと推測される。特性2）は，砂質 

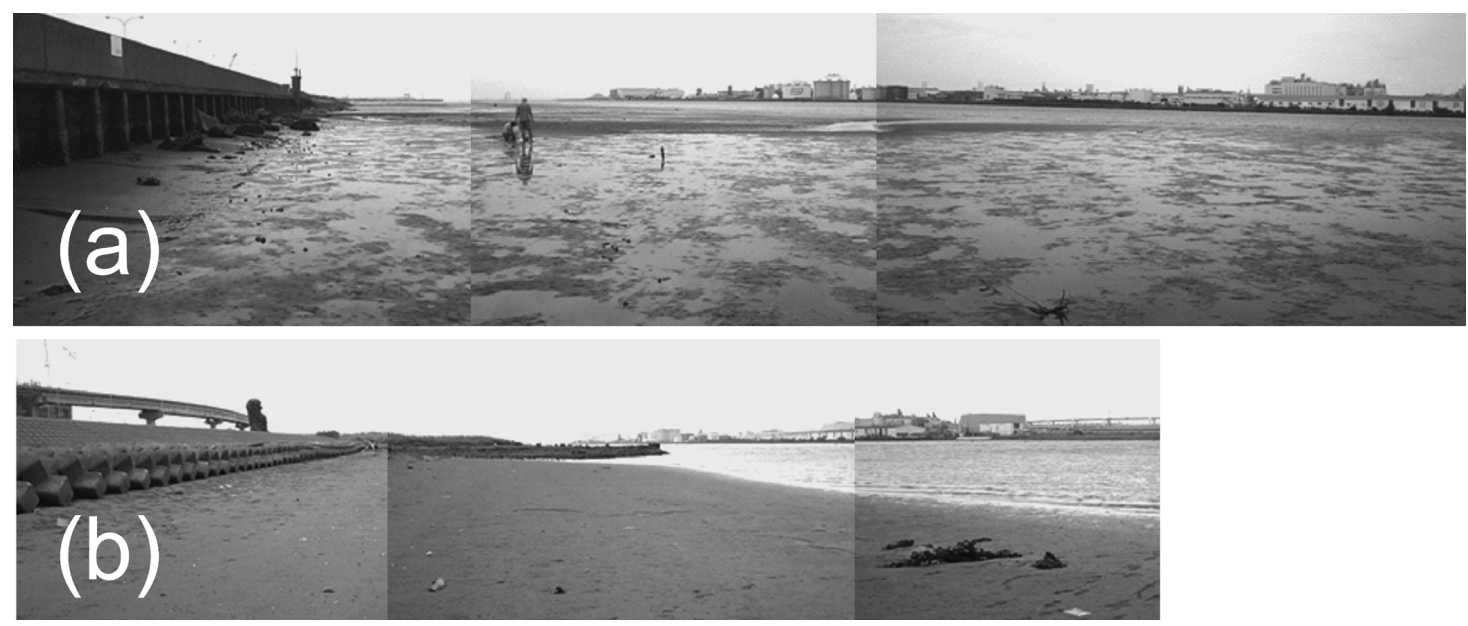

Fig. 9. Two different types of intertidal geomorphology in the Tama River Estuary: (a) mildly-sloping, wide tidal flat with slight depressions, over which small tidal creeks run or pools persist; (b) steep, narrow beach composed of compact sediment without any tidal creeks or pools. Photographs were taken at (a) Line 8 and (b) Line 6 at low tide.

干潟に生息する（市川市・東邦大学東京湾生態系研究セン ター 2007）という従来の知見と一致した。ただし本調査 域では底質の粒子サイズに河川流軸方向の勾配があったた め, ライン $1 \cdot 2$ での本種の不在・個体数低下（Fig. 2i）が 高い含泥率によるものか低い塩分によるものかは判別でき ない，底質粒子サイズについて本種の生息条件を明らかに するには，塩分と粒子サイズが独立している生息地を含む 様々な生息地での分布・環境調査を行う必要がある。特性 3）は，潮間帯中部に分布するという，小櫃川河口（千葉 県）で得られている従来の知見（大嶋・風呂田 1980）と 一致した。これは，本種の干出耐性が低いことを示唆す る。

特性4）5）は，主要なマクロベントスの中でも本種に特 徵的であった（Fig. 8). ORPは底質の好気的／嫌気的状態 の指標であり，一般的にORPが負の值をとり還元化した 底質では, 酸素不足と硫化物の存在が底生生物の生息を制 限する（Pearson \& Rosenberg 1978）。本種は主要なマクロ ベントスの中でも特にORPの高い底質に分布し，この分 布パターンは污染指標種として知られる Capitella sp. と正 反対のものであった（Fig. 8)。このことは，本種の低酸素 而性が特に低いことを示唆する。低酸素而性の低さを示唆 する知見は本種と同じ汽水性スナウミナナフシ属の北米種 Cyathura polita (Burbanck 1961) や西欧種 Cyathura carinata (Cardoso et al. 2004) でも得られていることから，これら の種は酸素要求性に関して本種と類似した生理特性をもつ と考えられる。

傾斜は波浪または潮流の強さと底質粒子のサイズと相互 に複雑に関連するが, 概ね, 傾斜の緩いところでは底質粒 子が小さく, 干出時に水が底質に保持されやすい（Raffaelli \& Hawkins 1996; McLachlan \& Brown 2006). 本調査地 では，底質の水分含量に顕著な違いはなかった。しかし， 緩傾斜地では底質上に小規模の澪筋や水たまりがみられ，
“ひたひたとした”景観を呈していた（Fig. 9a）一方，急傾 斜地では澪筋や水たまりはみられず, 底質は全体に締め固 まっているようにみえた (Fig. 9b)。このことから著者ら は, 緩傾斜地における干出時の底質上の澪筋や水たまりが 何らかの形で本種の好適環境を生み出しているのではない かと考元る. そのひとつには水の存在そのものが考えら れ，これは特性3）から推測された本種の干出耐性の低さ からも支持される。もうひとつには，水を介した酸素供給 が示唆される。一般的には緩傾斜地では底質は還元的にな りやすい（Raffaelli \& Hawkins 1996）が, 本調査地では傾 斜が緩いほどORPが高いという逆の相関がみられた（Fig. 8). 緩傾斜地では水はけが悪いことから，大気からの酸素 供給は減少すると考えられる。しかし，緩傾斜地で見られ た澪筋や水たまりの水は表層水に由来するものと考えら れ，表層水は大気と接し酸素を豊富に含むと考えられる。 したがって, 緩傾斜地では澪筋や水たまりを介して底質に 酸素の豊富な水が保持されることで底質が酸化的になり， 急傾斜地ではその水が底質に保持されずに排出されるため に底質が還元的になっているのかもしれない，そうだとす れば, 本種の緩傾斜への分布は, 酸素要求性の高さに起因 したと考えられる.

なお，本種の分布規定要因には，上述の物理的環境以外 に生物的環境も考えられる。しかし，本種の種内・種間相 互作用については知見が竞しいことから，本研究では生物 的環境は考慮しなかった。

\section{東京湾における近年の個体数減少の原因}

以上をふまえて，東京湾において本種が近年減少してい る（風呂田 2007, 2011）原因を推察する.

第 1 の原因には，河口周辺の遠浅の干潟の消失が考えら れる．20世紀前半まで，東京湾の海岸線には遠浅の干潟 が広がり，河川や水路がときに網目状になりこれらの干潟 
に注いでいた（農商務省水産局 1916; 古川 2011）。また当 時の空中写真（国土地理院 国土変遷アーカイブ空中写真 閲覧システム http://archive.gsi.go.jp/airphoto/) から，これ らの干潟は澪筋や水たまりのある “ひたひたとした” 景観 をしていることがわかる。これらの特徴は本種の生息環境 特性 1）4）と一致することから, 当時, 本種は東京湾各地 の干潟に広く生息していたと推測される.しかし1945年 以降, 特に 1960 74年には埋め立てが進み河川の直線化 も行われ（古川 2011）， その結果本種の生息に適した河口 周辺の遠浅の干潟が減少したと考えられる. 例えば, 東京 都の葛西周辺（旧江戸川河口周辺）の干潟では1970年代 前半には至るところに本種が分布していた（干潟研究会 1973, 1975; 日本鳥類保護連盟 - 環境庁 1973; 秋山 1974, 1975b）が，1970年代後半には埋め立てや河川工事, 地盤 沈下で干潟の多くの部分が消失し, 本種の分布地は減少し た（秋山 1976, 1977, 1978）。このようなことが東京湾各地 の干潟でおこり, 東京湾全体として本種の個体数が減少し たと推定される.

第2 の原因には, 東京湾の貧酸素化が考えられる. 東京 湾の底層では夏季に生じる貧酸素化により無生物域が形成 され, 特に1960年代後半以降はこれが顕著である（大 越・風呂田 2000; 風呂田 2011). 本種の生息環境特性 5）か ら示唆された貧酸素耐性の低さは, 東京湾の近年の酸素環 境の悪化が, 残存する干潟においても本種の分布域を狭め ている可能性を示唆する. 例えば, 谷津干潟（千葉県）で は1970年代には本種が出現していたが (干潟研究会 1975），1990年以降は確認されていない（環境庁ら 1996; 風呂田・鈴木 1999). 小櫃川河口（千葉県）では 1970 年代 には本種が普通に確認されているが（秋山 1975a; 大嶋・ 風呂田 1980), 近年ではその発見は稀である（風呂田 2007). 小櫃川河口については酸素環境悪化を示すデータ はないが, 谷津干潟では底質の ORPは標準的な干潟の下 限值より低く（風呂田・鈴木 1999）, これにより本種が生 息できなくなった可能性がある。 また, 多摩川河口では過 去の本種の分布データがないが, 多摩川河口域では貧酸素 水が観測されていること（八木ら 2007）から, 酸素環境 の悪化の結果現在の狭い分布になっている可能性があると 考えられる.

以上のことから，本種の保全の際には，河川の干潟への 注ぎ方や干潟の地形，それにともなう澪筋や水たまり，ま た酸素環境に留意すべきである可能性がある．特に地形や 澪筋については, 干潟の底生生物の分布と関連する要因と して着目した研究は岸野ら（2010）など多くはなく, 本研 究は, 干潟の底生生物の保全を考える際にはこれらにも着 目すべき場合があることを示すものである．ただし本研究 の結果は 1 つ生息地における分布・環境調査から得られ たものであるため, 本種の保全に向けた正確な議論を行う ためには, 本研究から示唆された生理特性を検証する室内 実験や，他の生息地における分布・環境調査を行うことが
必要だろう。

謝辞：本研究を行うにあたり, 東京大学大学院農学生命科学研 究科の佐野光彦教授には原稿を読んでいただき，修正に有益な助 言やコメントをいただいた。同研究科の植松幸希氏には地形測量 に協力していただくとともにCCAを行う際のソフトウェア操作 方法を教えていただいた．同研究科（現・アクセンチュア(株)) の藤木宣成氏には地形測量に協力していただいた。同研究科 (現・東電環境エンジニアリング(株)）の木塚智洋氏には 2009 年 のマクロベントス採集とソーティングに協力していただいた。同 研究科の田中裕一氏には 2009 年のマクロベントスのソーティング に協力していただくとともに原稿の一部の表現の修正に有益なコ メントをいただいた．同研究科の杉原奈央子氏と金井貴弘氏には 原稿の一部を読んでいただき修正に有益なコメントをいただい た. 島根県環境保健公社の戸田顕史氏には考察におけるアイデア を引き出す情報をいただいた，東邦大学東京湾生態系研究セン ターの風呂田利夫センター長にはムロミスナウミナナフシの過去 の生息状況を調べるにあたって必要な多くの文献貸出の労をとっ ていただいた，以上を記して謝意を表す。

\section{引用文献}

秋山章男 1974. 底生動物. 暮西沖公園野鳥生息現況調查報告書, 昭和 48年度, 日本野鳥の会・干潟研究会, pp. 98-120.

秋山章男 1975a. 千葉県の干潟の環境と生物相. 日本生物教育会 第30回全国大会 (千葉大会) 実行委員会・「千葉県の生物」編 集部(編), 千葉県の生物, pp. 172-180.

秋山章男 1975b. 底生動物。葛西沖公園野鳥生息現況調查報告書, 昭和 49 年度, 日本野鳥の会, pp. 43-83.

秋山章男 1976. 底生動物着生状況調查. 東京都港湾局委託調 查 葛西沖公園野鳥生息現況調查報告書, 昭和 50 年度, 日本野 鳥の会, pp. 52-76.

秋山章男 1977. 葛西人工渚に扔ける底生動物着生状況調査. 東京 都港湾局委託調査 暮西沖公園野鳥生息現沉調查報告書, 昭和 51年度, 日本野鳥の会, pp. 37-66.

秋山章男 1978. 葛西人工渚に招ける底生動物着生状況調査. 東京 都港湾局委託調査 葛西沖公園野鳥生息現沉調査報告書, 昭和 52 年度, 日本野鳥の会, pp. 61-80.

ter Braak, C. J. F. and Smilauer, P. 2002. CANOCO Reference Manual and CanoDraw for Windows User's Guide: Software for Canonical Community Ordination (version 4.5), Microcomputer Power, Ithaca, New York, USA, 500 pp.

Burbanck, W. D. 1961. The biology of Cyathura sp., an estuarine isopod of eastern North America. Verhandlungen der Internationalen Vereinigung für Theoretische und Angewandte Limnologie, 14: 968-971.

Cardoso, P. G., Pardal, M. A., Raffaelli, D., Baeta, A. and Marques, J. C. 2004. Macroinvertebrate response to different species of macroalgal mats and the role of disturbance history. Journal of Experimental Marine Biology and Ecology, 308: 207-220.

風呂田利夫 2007. 東京湾. 飯島明子(編), 浅海域生態系調查（干 潟調査）報告書，環境省自然環境局 生物多様性センター，山 梨, pp. 39-47.

風呂田利夫 2011. 底生生物とその生息環境. 東京湾海洋環境研究 委員会(編), 東京湾-人と自然のかかわりの再生, 恒星社厚生 閣, 東京, pp. 136-143.

風呂田利夫・鈴木嘉平 1999. 東京湾奥部谷津干潟の 1986-87年冬 期における底質環境ならびにマクロベントスの生息状況と垂直 状況. 日本ベントス学会誌, 54: 36-43.

古川恵太 2011. 江戸時代以降の埋立と変遷. 東京湾海洋環境研究 委員会 $($ 編), 東京湾-人と自然のかかわりの再生, 恒星社厚生 
閣，東京，pp. 44-46.

市川市・東邦大学東京湾生態系研究センター 2007. 干潟ウォッチ ングフィールドガイド図鑑, 誠文堂新光社, 東京, $144 \mathrm{pp}$.

干潟研究会 1973. 葛西周辺干潟の生態的研究-1972年における生 物と環境の現況, $125 \mathrm{pp}$.

干潟研究会 1975 . 開発の干潟に及ぼす影響に関する研究II, $98 \mathrm{pp}$.

飯島明子・和田恵次 2007. 干潟底生生物の地理的な特徵. 飯島明 子(編), 浅海域生態系調査（干潟調査）報告書，環境省自然環 境局 生物多様性センター, 山梨, pp. 127-144.

石塚明男 1986. 粒度分析. 日本海洋学会 (編), 沿岸環境調査又 ニュアル 底質・生物篇, 恒星社厚生閣, 東京, pp. 31-34.

IUBS (International Union of Biological Sciences) 1959. Symposium on the classification of brackish waters, final resolution, the Venice System for the classification of marine waters according to salinity. Archivio di Oceanografia e Limnologia, 11 (suppl): 243-245.

Kanaya, G. and Kikuchi, E. 2008. Spatial changes in a macrozoobenthic community along environmental gradients in a shallow brackish lagoon facing Sendai Bay, Japan. Estuarine, Coastal and Shelf Science, 78: 674-684.

環境庁・ 千葉県・習志野市 1996. 谷津干潟環境調査報告書, 179 pp.

加藤和弘・篠沢健太 1995. 多変量解析による生物相の分析と, そ の河川環境管理への応用. ランドスケープ研究，58: 105-108.

川合禎次 - 谷田一三 2005. 日本産水生昆虫-科 - 属 - 種への検 索, 東海大学出版会, 神奈川, $1342 \mathrm{pp}$.

岸野 底・木邑聡美 - 唐澤恒夫 - 國里美樹 - 野元彰人 - 和田恵 次 2010. 汽水性希少カ二類クマノエミオスジガニDeiratonotus kaoriaeとアリアケモドキD. cristatus（ムツハアリアケガニ 科）の三重県櫛田川河口域における出現状況. 日本ベントス学 会誌, 65: 6-9.

McLachlan, A. and Brown, A. 2006. The Ecology of Sandy Shores, Academic Press, Boston, 373 pp.

日本鳥類保護連盟 - 環境庁 1973. 干潟鳥類保護対策調査報告書, $64 \mathrm{pp}$.
西栄二郎・田中克彦 2007. 神奈川近海の干潟・汽水域に産する環 形動物多毛類. 神奈川自然誌資料, 28: 101-107.

農商務省水産局 1917. 浅海利用調査報告 第 1 報 東京湾, $97 \mathrm{pp}$.

Nunomura, N. 1974. A new anthurid isopod from the estuary of the Muromi river, northern Kyushu, Japan. Bulletin of the Osaka Museum of Natural History, 28: 13-16.

布村 昇 1995. スナウミナナフシ科. 西村三郎(編), 原色検索日 本海岸動物図鑑（II），保育社，東京，pp. 209-212.

布村 昇 2007. 節足動物門 軟甲綱 等脚目. 飯島明子(編), 浅海 域生態系調査（干潟調査）報告書，環境省自然環境局 生物多 様性センター, 山梨, p. 200.

大越和加・風呂田利夫 2000. 平場の生物. 沼田 真 - 風呂田利夫 (編), 東京湾の生物誌, 築地書館, 東京, pp. 86-109.

大嶋 剛・風呂田利夫 1980. 小櫃川河口干潟周辺における底生動 物の分布. 東邦大学理学部海洋生物学教室 -千葉県生物学会 (編), 千葉県木更津市小櫃川河口干潟の生態学的研究I, pp. 45-68.

Pearson, T. H. and Rosenberg, R. 1978. Macrobenthic succession in relation to organic enrichment and pollution of the marine environment. Oceanography and Marine Biology: an Annual Review, 16: 229-311.

Raffaelli, D. and Hawkins, S. 1996. Intertidal Ecology, Kluwer Academic Publishers, Dordrecht, 356 pp.

鈴木孝男・木村昭一・木村妙子 2000. 干潟生物調査ガイドブッ ク一東日本編一, 日本国際湿地保全連合, 東京, $120 \mathrm{pp}$.

八木 宏・江連伸明・井瀬 肇・Pokavanich, T. ・灘岡和夫 ・ 諸星 一信・古土井健・有路隆一・森重輝政・小林 聡 2007. 東京湾 羽田周辺水域における貧酸素水塊と懸濁物質の時空間変動特 性. 海岸工学論文集, 54: 1036-1040.

山本晃一 2008. 多摩川河川汽水域に及ぼした人為作用と汽水域の 変化. 財団法人河川環境管理財団 (編), 河川汽水域, 技報堂出 版, 東京, pp. 5-30.

山室真澄 1996. 感潮域の底生動物. 西條八束 - 奥田節夫 (編), 河 川感潮域—その自然と変貌一, 名古屋大学出版会, 名古屋, pp. 151-172. 